\title{
MENGATASI PERMASALAHAN SAMPAH DI LOKASI WISATA ALAM GUNUNG DI JAWA BARAT
}

\author{
Ari Ganjar Herdiansah \\ Universitas Padjadjaran \\ E-mail: ari.ganjar@unpad.ac.id
}

\begin{abstract}
ABSTRAK. Seiring dengan meningkatnya antusias warga masyarakat dalam melakukan kegiatan rekreasi di alam bebas, sampah kini menjadi permasalahan di berbagai lokasi wisata alam gunung di Jawa Barat. Artikel ini mendeskripsikan kegiatan pengabdian pada masyarakat (PPM) dosen Universitas Padjadjaran (Unpad) dalam bentuk sosialisasi dan edukasi kepada masyarakat agar bersama-sama mengatasi permasalahan sampah tersebut. Karena dalam kondisi pandemi, kegiatan PPM dilakukan dalam bentuk Webinar dengan mengundang para pembicara dari kalangan aktivis kegiatan alam bebas, aktivis lingkungan, dan akademisi. Sementara itu, para peserta Webinar terdiri dari kelompok-kelompok pecinta alam dan para praktisi kegiatan alam bebas di Jawa Barat. Melalui kegiatan ini, peserta mendapatkan pemahaman tentang pentingnya berperilaku tidak mengotori lokasi wisata alam dengan sampah yang dibawanya. Para peserta juga mendapatkan pengetahuan tentang berkegiatan di alam bebas tanpa menghasilkan sampah (zero-waste).
\end{abstract}

Kata kunci: sampah; lingkungan; wisata alam; sosialisasi

\section{OVERCOMING THE WASTE PROBLEM IN MOUNTAIN TOURISM SITES IN WEST JAVA}

\begin{abstract}
Along with the increasing of people's enthusiasm in carrying out outdoor recreational activities, waste is now a problem in various mountain tourism sites in West Java. This article describes the community service activities (PPM) of lecturers of Universitas Padjadjaran (Unpad) in the form of socialization and community education to overcome the waste problem. Because a pandemic, the PPM was conducted in a Webinar by inviting speakers from outdoor activists, environmental activists, and academics. Meanwhile, the participants consist of groups of activits and outdoor activists. Through the Webinar, participants understand the importance of not polluting mountain tourism sites with the litter they carry. The participants also gained knowledge about practicing outdoor activities without producing waste (zero-waste).
\end{abstract}

Keywords: waste; environment; nature tourism; socialization

\section{PENDAHULUAN}

Kegiatan rekreasi di alam bebas semakin digemari oleh warga masyarakat. Berbagai lokasi wisata alam gunung di Jawa Barat, seperti di sekitaran Bandung, Bogor, dan Garut senantiasa menjadi destinasi favorit bagi wisatawan lokal. Tempattempat tersebut dipenuhi oleh pengunjung yang ingin menikmati keindahan alam dan segarnya udara di pegunungan. Situasi pandemi yang memaksa warga berkegiatan di rumah semakin meningkatkan antusiasme warga untuk melepaskan kepenatan di lokasi-lokasi wisata alam ketika pemerintah memberlakukan pelonggaran Pemberlakuan Pembatasan Kegiatan Masyarakat (PPKM).

Namun, seiring dengan meningkatnya kunjungan wisatawan ke berbagai destinasi wisata alam gunung di Jawa Barat, permasalahan sampah semakin memprihatinkan. Di beberapa lokasi pendakian, seperti di Gunung Cikuray dan di Gunung Gede, sampah tampak berserakan dan berceceran di sepanjang jalur pendakian atau di tempat kemping (camp site) (Nurfadhilah, Komalasari, \& Prabawa, 2020)(Taufiqurrahman, 2021). Sumber dari sampahsampah itu tidak lain selain berasal dari para pendaki yang berkunjung (Wirawan, 2015). Di beberapa tempat kegiatan alam non-pendakian pun tidak kalah bermasalah. Sampah wisawatan tidak terkelola dengan baik, bahkan ada yang dibiarkan menggunung di pinggiran jalan desa. Persoalan sampah di lokasi wisata alam telah menjadi masalah yang merugikan warga. Berdasarkan pengamatan salah satu anggota tim PPM di suatu camp site di daerah Sumedang, gundukan sampah wisatawan yang tidak terurus kemudian tumpah dan mengotori area pemukiman warga di sekitar lokasi.

Kotoran sampah di berbagai lokasi wisata alam tidak hanya merugikan masyarakatnya, tetapi juga lingkungan alam, termasuk binatang-binantang penghuni alam tersebut (Broder, 2019). Tidak sedikit binatang yang memakan sampah plastik yang ditinggalkan atau dibuang oleh pengunjung. Sampah plastik yang sulit terurai juga telah terbukti dapat merusak ekosistem, sehingga tumbuhan dan hewanhewan liar tidak dapat hidup sebagaimana mestinya. Terganggunya keseimbangan alam, pada gilirannya, akan merugikan kehidupan manusia. Sebab, wilayah pegunungan merupakan sumber dari berbagai kebutuhan dasar manusia. Di sana terdapat mata air, suplai oksigen, dan berbagai macam sumber makanan ( $\mathrm{Hu} \& \mathrm{Hu}, 2014)$. 
Dalam mengatasi persoalan sampah, telah banyak civitas akademika perguruan tinggi yang melakukan kegiatan PPM. Beberapa menekankan pada aspek pengelolaan secara kreatif, seperti yang dilakukan oleh (Fordian, Lavinia, Rianto, \& Azis 2017) dan Darmawan, (2020) yang melakukan penyuluhan pemilahan sampah organik dan non-organik di kalangan warga desa di Kec. Jatinangor. Sebagian lain menangkat tema insentif dari pemilahan pengelolaan sampah, misalnya Mubarak, Marasabessy, \& Aryuni (2019) yang melakukan penyuluhan bank sampah di Ternate dan Irawatie, Iswahyuni, Setiyawati, \& Afriani (2021) tentang pengelolaan bank sampah di masa pandemi Covid-19. Sementara itu, PKM tentang pengentasan masalah sampah di hutan belum banyak dilakukan. Salah satu dari yang sedikit itu dilakukan Indriawati \& Retnowaty (2018) tentang pelestarian pesisir dan hutan mangrove Manggar dari pencemaran sampah.

Berdasarkan permasalahan yang telah diuraikan di atas, tim akademisi Universitas Padjadjaran yang terdiri dari seorang dosen dan 10 (sepuluh) orang mahasiswa melakukan kegiatan PPM dosen tentang persoalan sampah di lokasi wisata alam. Kegiatan tersebut dikemas dalam bentuk Webinar bertema "Mengatasi Persoalan Sampah di Lokasi Wisata Alam," yang dilaksanakan pada Kamis, 5 Agustus 2021. Inti dari kegiatan ini adalah sosialisasi dan edukasi kepada masyarakat, terutama mereka yang gemar beraktivitas di alam terbuka agar meningkatnya pemahaman tentang cara memperlakukan sampah di lokasi-lokasi wisata alam. Harapannya, gagasan tentang perilaku ramah lingkungan yang terbangun melalui kegiatan Webinar tersebut dapat terdiseminasikan secara lebih luas lagi. Para peserta dapat menjadi agen yang menyebarkan gagasan dan kesadaran tentang permasalahan sampah di lingkungan pergaulannya masing-masing.

\section{METODE}

Program pengabdian pada masyarakat ini dilakukan dengan metode edukasi masyarakat, yaitu memberikan pengetahuan tentang persoalan sampah disertai keterampilan untuk meminimalisir sampah bagi kalangan wisatawan/pendaki. Program tersebut terdiri dari serangkaian kegiatan yang berujung pada acara Webinar. Kegiatan didahului dengan identifikasi masalah tentang persoalan sampah di lokasi-lokasi wisata alam gunung di Jawa Barat. Tim melakukan diskusi internal tentang permasalahan sampah di lokasi wisata alam berdasarkan pengalaman dan pengamatan tiaptiap anggota tim. Poin-poin hasil diskusi kemudian dieksplorasi lebih lanjut dengan mencari informasi yang relevan melalui berbagai sumber yang tersedia di Internet, antara lain berita online, Youtube, dan Facebook. Dari hasil eksplorasi tersebut, beberapa sumber mengonfirmasi pengalaman anggota tim, bahwa permasalahan sampah di beberapa lokasi wisata alam gunung utamanya di Jawa Barat cukup memprihatinkan.

Berdasarkan identifikasi masalah yang telah diperoleh, tim merancang gagasan apa yang bisa diperbuat oleh tim berdasarkan kapasitas dan kompetensi masing-masing anggota. Program pertama yang dilakukan oleh tim adalah membuat e-poster dengan konten tentang permasalahan sampah dan ajakan kepada masyarakat agar lebih peduli lingkungan ketika berwisata alam. Setiap anggota tim membuat konten yang kemudian menyebarkannya melalui berbagai platform media sosial, seperti Instagram, secara berkala dari mulai 10 Juli 2021. Program berikutnya adalah mendalami permasalahan dengan para aktivis dengan cara berdialog melalui Zoom Meeting. Kegiatan tersebut dilaksanakan pada 26 Juli 2021 dengan para aktivis dari Wahana Lingkungan Hidup Indonesia (Walhi) dan Komunitas Pendaki Gunung Bandung (KPGB). Melalui pendalaman isu bersama para aktivis lingkungan dan pegiat alam bebas, tim memperoleh isu-isu yang lebih spesifik untuk diangkat dan didiskusikan pada acara Webinar.

Program akhir dari kegiatan ini adalah penyelenggaraan acara Webinar dengan tema "Mengatasi Persoalan Sampah di Lokasi Wisata Alam."Acara tersebutmenghadirkan para pembicara, antara lain Irhash Ahmady (Walhi Jabar), Gan Gan Jatnika (KPGB), Siska Nirmala (aktivis Zero Waste Adventure), dan Mustabsyirotul Ummah (dosen Departemen Ilmu Politik FISIP Unpad). Sementara itu, para peserta yang diundang di antaranya dari kalangan pecinta alam di lingkungan kampus, kelompok-kelompok pecinta alam di Jawa Barat, dan mahasiswa, dan warga masyarakat lainnya yang tertarik dengan isu permasalahan sampah. Acara Webinar tersebut terjalin berkat kejasama kemitraan dengan KPGB, Walhi Jabar, dan Pemandu Geo Wisata (PGW) Jawa Barat. Dalam memeriahkan acara, beberapa sponsor telah menyumbang door prize kepada pembicara dan peserta, yaitu Kinabalu Outdoor dan Quarzel. Acara Webinar dimulai dengan sambutan dan pengenalan isu dari tim PPM, paparan dari para pembicara, dan diakhiri sesi tanya jawab serta diskusi.

\section{HASIL DAN PEMBAHASAN}

\section{Diseminasi E-Poster tentang Masalah Sampah di Lokasi Wisata Alam}

Program penyebaran e-poster ditujukan untuk memberikan pengetahuan kepada masyarakat 
tentang permasalahan sampah di lokasi wisata alam gunung. Tujuannya, masyarakat dapat mengubah perilakunya agar lebih peduli lingkungan, terutama dalam memperlakukan sampah yang dibawanya, ketika mereka berekreasi di alam bebas. Dengan menyebarkan e-poster ini di berbagai media sosial yang dimiliki oleh tiap-tiap anggota tim, seperti Instagram dan Facebook, diharapkan masyarakat yang terhubung dengan aku media sosial anggota tim dapat menyimak kontennya dan kesadarannya tentang permasalahan sampah meningkat. Dalam rangka lebih memperluas cakupan warga internet (netizen), postingan e-poster disertai dengan berbagai tagar, seperti \#sampah, \#pendaki, \#gunungindonesia, \#wisataalam, dan \#jagalingkungan.

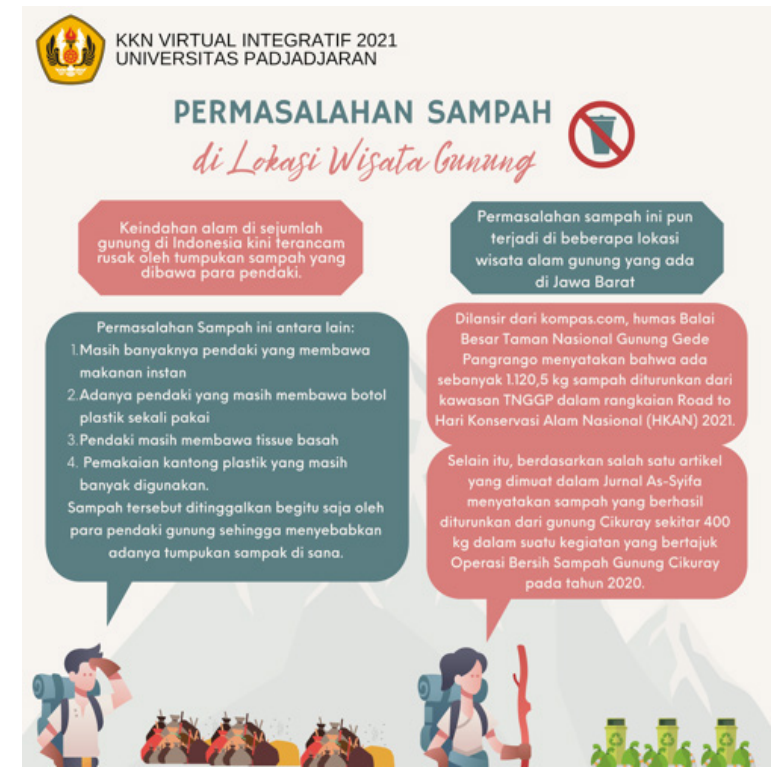

Gambar 1. E-Poster Permasalahan Sampah di Lokasi Wisata Gunung

E-poster yang pertama disebar terkait dengan permasalahan sampah di lokasi wisata alam gunung. Konten ini diangkat untuk memberikan informasi dan pengetahuan kepada masyarakat luas bahwa saat ini, permasalahan sampah semakin krusial seiring dengan makin maraknya warga yang mengunjungi lokasi-lokasi wisata alam tapi kurang memperhatikan penanganan sampah yang mereka bawa. Isu tersebut diarahkan secara spesifik kepada para pendaki, karena selama ini mereka yang dianggap bertanggungjawab atas tumpukan dan serakan sampah baik di jalur pendakian maupun di puncak gunung. Namun demikian, konten inipun diarahkan pada masyarakat umum yang saat ini memang semakin antusias berekreasi ke alam bebas.

E-poster kedua yang dibuat oleh tim berisi tips tentang mengurangi sampah di gunung dengan menggunakan prinsip zero-waste. Inti dari prinsip zero-waste adalah pengelolaan yang sedapat mungkin tidak menghasilkan sampah (Hamid, Yahaya, \& Asrina, 2020). Pada kegiatan alam bebas, prinsip ini diterapkan di mana pendaki ataupun wisatawan yang hendak berekreasi agar tidak membawa barang dan perlengkapan (terutama makanan) yang dapat menghasilkan sampah. Cara tersebut bisa ditempuh dengan antara lain membawa makanan alami yang tidak dikemas oleh kemasan plastik, menggunakan wadah atau tempat yang dapat digunakan berulang kali, menggunakan serbet atau kain lap untuk menghindari pemakaian tisu, dan menggunakan tas untuk mengurangi atau menghindari pemakaian kantok plastik. Dengan cara-cara tersebut, pendaki atau wisatawan dapat seminimal mungkin membawa sampah, sehingga tidak berpotensi mengotori lokasi wisata alam. Sama halnya dengan e-poster pertama, e-poster yang kedua juga disebarkan melalui media sosial Instagram dan Facebook.

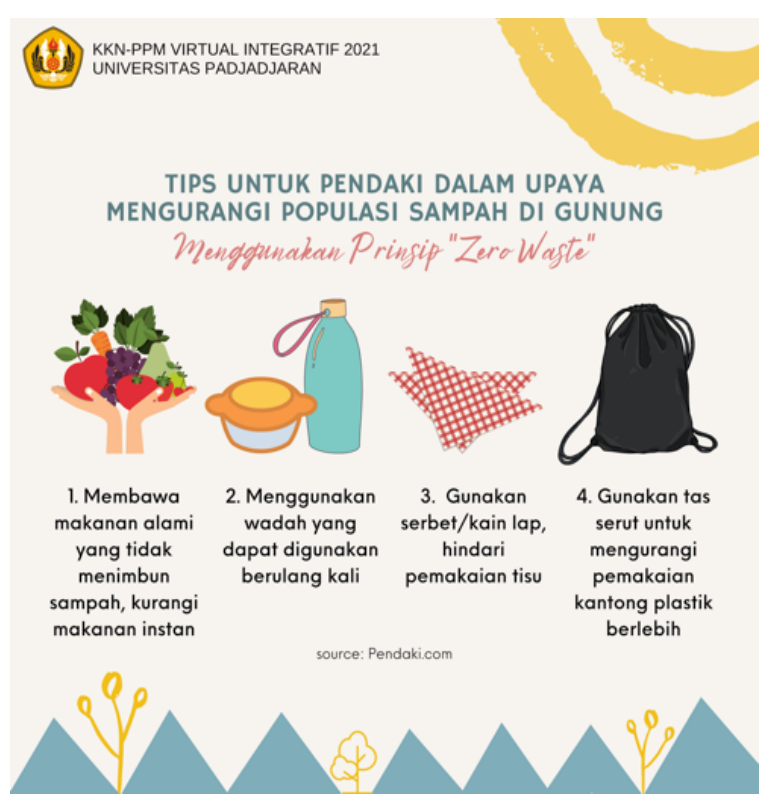

Gambar 2. E-Poster Tips Mengurangi Sampah di Gunung dengan Prinsip Zero-Waste

\section{Webinar Mengatasi Persoalan Sampah di Lokasi Wisata Alam}

Kegiatan puncak dari PPM ini adalah acara Webinar yang mendiskusikan isu-isu seputar permasalahan sampah di lokasi wisata alam gunung di Jawa Barat. Acara yang berlangsung dari pukul 16.00 hingga 18.00 ini diikuti oleh sekitar 100 orang peserta pada Zoom Meeting dan 16 orang pada YouTube Live. Informasi terkait acara Webinar disebarkan melalui jaringan komunitas pecinta alam dan berbagai organisasi lingkungan. E-poster, sebagaimana ditampilkan pada gambar 3, diposting di berbagai akun Instagram dan Facebook komunitas pecinta alam. Supaya memperluas khalayak, acara ini juga disiarkan secara langsung melalui Youtube Departemen Ilmu Politik FISIP Unpad. Di saluran YouTube, acara Webinar yang isinya paparan dan diskusi dapat disimak kapanpun oleh masyarakat, sehingga diharapkan dapat berdampak dalam jangka waktu yang panjang. 


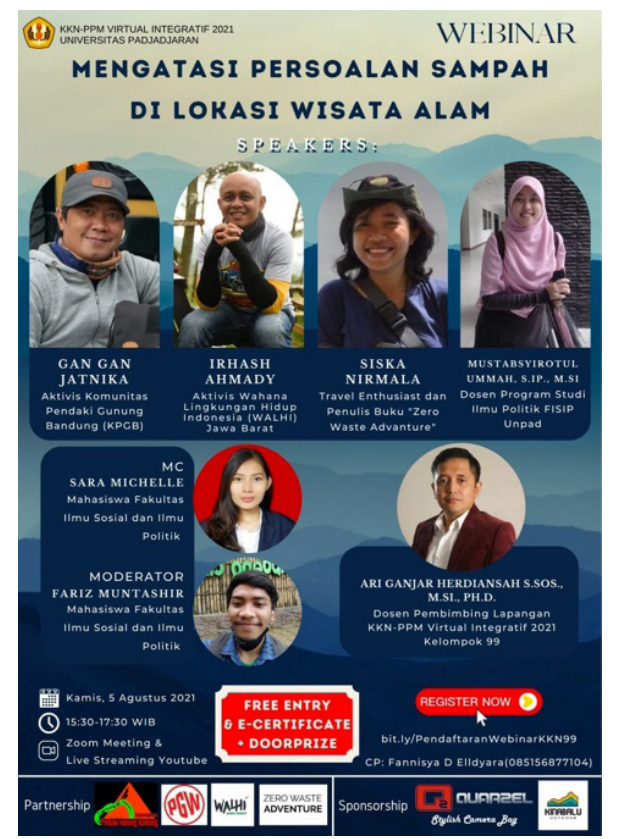

Gambar 3. E-Poster Acara Webinar

Pembicara pertama, yaitu Gan Gan Jatnika yang merupakan aktivis dari KPGB dan PGW menyampaikan tentang fase-fase perilaku pendaki dalam memperlakukan sampah. Ia menekankan bahwa persoalan sampah meningkat seiring dengan membesarnya jumlah warga yang memilih hobi berkegiatan di alam bebas. Sekitar tahun 1990an hingga 2000an, sampah belum menjadi persoalan di lokasi wisata alam. Sebab, para pendaki terbilang masih sedikit. Selain itu, resesi ekonomi pada 1998 mempengaruhi rendahnya minat orang untuk mendaki. Mahalnya harga peralatan pendakian menghambat orang-orang untuk menjalani hobi sebagai pendaki. Namun, mulai 2010an, orangorang mulai banyak berwisata ke pegunungan dan sebagian menjadi pendaki seiring ekonomi yang makin membaik. Tapi, sejak saat itu pula sampah manjadi masalah. Terlebih lagi ketika kegiatan pendakian menjadi 'viral' di media sosial dan mengundang semakin banyak orang berkegiatan di alam bebas. Tidak sedikit dari para pendaki tidak mengindahkan soal sampah. Banyak pendaki yang membuang sampah begitu saja, sehingga sampah plastik berserakan di berbagai tempat pendakian.

Pembicara kedua, Irhash Ahmadi, merupakan aktivis lingkungan dari Walhi Jawa Barat. Dalam paparannya, Irhash mengungkapkan persoalan sampah di lokasi wisata alam sebagai bagaian dari persoalan tata kelola lingkungan. Dalam melihat permasalahan sampah, Walhi memiliki sudut pandang yang berbeda dengan komunitas pecinta alam, di mana Walhi lebih mengedepankan pendekatan yang menyoroti dari aspek kebijakan dan advokasi. Permasalahan sampah di lokasi wisata alam tidak terlepas dari soal pengelolaan lingkungan di Jawa Barat. Komersialisasi lingkungan alam yang tidak dibarengi dengan aspek tata kelola berkelanjutan turut berkontribusi pada kurangnya pengelolaan sampah.

Pembicara berikutnya yaitu Siska Nirmala, seorang aktivis yang gencar mengkampanyekan zero-waste. Beliau aktif melakukan pendakian ke berbagai gunung di Indonesia dengan menerapkan prinsip zero-waste. Kegiatannya tersebut didokumentasikan dalam bentuk buku Zero Waste Adventure. Siska Nirmala senantiasa mengedukasi masyarakat terutama terhadap kalangan pendaki tentang pentingnya menerapkan perilaku ramah lingkungan dengan sedapat mungkin tidak membawa barangbarang yang bisa menjadi sampah. Para pendaki diharapkan tidak membawa makanan yang dikemas oleh bungkus plastik. Sebagai alternatif, pendaki bisa mempersiapkan dulu makanan dan minuman di rumah dan dikemas dalam wadah yang memiliki nilai lebih, misalnya dari segi harga. Dengan begitu, pendaki akan membawa kembali wadah tersebut dan tidak meninggalkan sampah di gunung. Apabila setiap pendaki dapat menerapkan prinsip tersebut, gunung-gunung di Jawa Barat akan jauh lebih bersih dari sampah.

Pembicara terakhir dalam acara Webinar adalah Mustabsyirotul Ummah, dosen Departemen Ilmu Politik FISIP Unpad, yang menaruh perhatian pada kajian politik lingkungan. Menurutnya, persoalan sampah di tempat wisata bukan hanya disebabkan oleh para pendaki atau pengunjung. Tetapi juga kurang baiknya penanganan sampah oleh pengelola lokasi-lokasi wisata alam. Hal itu, apabila dilihat dari perspektif lebih luas (makro) juga terkait pengelolaan lingkungan oleh pemerintah. Oleh sebab itu, gerakan aktivisme yang dilakukan oleh para aktivis lingkungan dan berbagai kelompok pecinta alam kurang berdampak signifikan karena yang mereka hadapi adalah juga persoalan politik dan pemerintahan. Karenanya, gerakan aktivis dalam menyadarkan masyarakat tentang permasalahan sampah juga perlu dibarengi dengan pendekatan politis. Misalnya, menyalurkan aspirasi terkait persoalan tersebut kepada anggota DPRD Jawa Barat atau kepada partai politik. Para aktivis juga bisa melakukan kontrak politik, misalnya dengan mendukung partai politik tertentu dengan 'imbalan' partai politik tersebut turut memperjuangan persoalan lingkungan. Salah satunya adalah pengelolaan sampah di lokasi wisata alam gunung.

Setelah sesi paparan dari para pembicara, acara Webinar dilanjutkan dengan sesi tanya jawab dan diskusi dari para peserta. Di sesi ini, antusiasme para peserta sangat tinggi dalam merespons isu dan materi yang telah disampaikan para pembicara. Beberapa pertanyaan yang menarik antara lain tentang bagaimana mengubah perilaku pendaki yang 
baru-baru (newbie) agar tidak membuang sampah sembarangan dan bagaimana menerapkan prinsip zero-waste secara konsisten. Untuk pertanyaan pertama, dari hasil diskusi mengemuka pendapat di era media sosial dan Internet ini, orang-orang dengan mudah mempelajari destinasi pendakian, peralatan pendaki, dan cara-cara mendaki. Akibatnya, banyak orang yang tidak memahami aturan pendakian secara benar, termasuk perilaku menghargai alam. Karena itu, berbagai komunitas pendaki di Jawa Barat diharapkan agar lebih intensif merangkul para pendaki baru agar diberikan pengetahuan dan sosialisasi perilaku mencintai lingkungan alam. Untuk pertanyaan kedua, pembicara menyarankan agar penerapan zero-waste dilakukan secara bertahap dalam kehidupan sehari-hari, seperti mulai menggunakan tumbler dan meninggalkan kebiasaan membeli air minum kemasan. Disarankan juga untuk tidak menghakimi orang-orang yang belum menerapkan zero-waste agar mereka tidak antipati terhadap prinsip tersebut. Prinsip zero-waste akan lebih efektifapabila dikampanyekan secara persuasif.

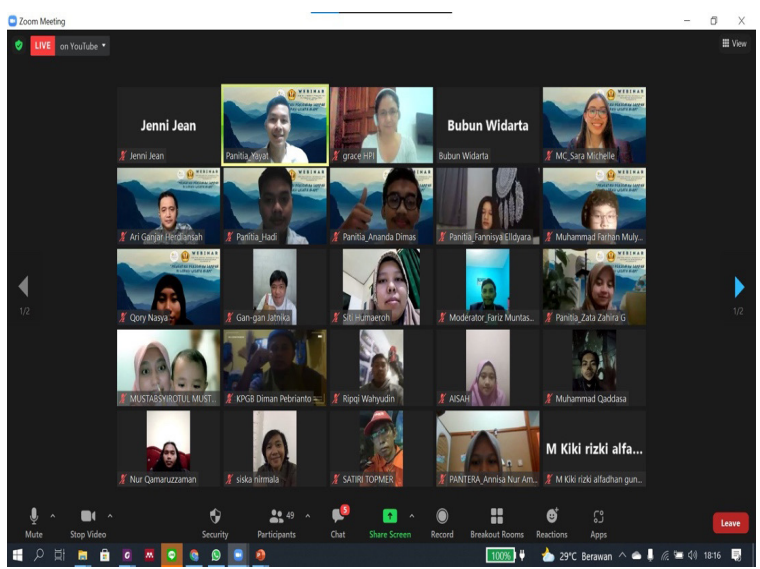

Gambar 3. Suasana Webinar

Berdasarkan kegiatan Webinar dengan mengundang para narasumber tersebut di atas, kegiatan ini telah meningkatkan kesadaran di kalangan peserta tentang betapa krusialnya persoalan sampah di lokasi wisata alam gunung Jawa Barat. Para peserta, yang kebanyakan dari kalangan pendaki, terdorong untuk lebih memperhatikan kelestarian alam setelah Gan Gan Jatnika dan Irhash Ahmadi menunjukkan kondisi tempat-tempat wisata alam gunung saat ini yang semakin memprihatikan oleh masalah sampah. Para peserta juga mendapatkan keterampilan tentang bagaimana cara meminimalisir sampah di lokasi wisata alam dengan menerapkan prinsip Zero Waste dari Siska Nirmala. Terakhir, dari Mustabsyirotul Ummah, peserta juga memperoleh pengetahuan tentang aspek politik dalam pengelolaan lingkungan yang dapat ditempuh oleh komunitas atau kelompok pemerhati lingkungan dalam rangka mengatasi persoalan sampah dari sisi kebijakan atau pemerintahan.

\section{SIMPULAN}

Masalah sampah merupakan persoalan klasik. Berbagai upaya yang telah dilakukan baik oleh pemerintah maupun masyarakat belum membuahkan hasil yang diharapkan. Padahal, teknologi yang berkembang untuk menangani masalah sampah semakin canggih. Persoalannya terletak pada perilaku masyarakatnya itu sendiri. Maraknya masalah sampah di lokasi wisata alam gunung semakin menambah beban bagi kelestarian lingkungan di Jawa Barat. Berdasarkan hasil eksplorasi isu oleh tim PPM dan diskusi pada Webinar, permasalahan sampah tidak terlepas dari perilaku masyarakat dan tata kelola lingkungan yang kurang memadai. Melalui Webinar ini, pengetahuan tentang krusialnya isu sampah di lokasi wisata alam gunung telah didiseminasikan. Para peserta juga antusias dalam membahas isu tersebut dan memberikan berbagai macam pandangan serta solusi yang dapat dilakukan baik oleh individu masyarakat, pemerintah, dan swasta atau pengelola tempat wisata alam. Video acara Webinar yang telah ditayangkan melalui kanal YouTube dapat diakses secara luas oleh masyarakat, sehingga pesan dari kegiatan PPM ini dapat berimplikasi lebih besar bagi perubahan perilaku masyarakat yang berkegiatan di lokasi wisata alam. Kegiatan PPM ini tentu tidak terlepas dari berbagai kekurangan, antara lain tidak melibatkan pihak pemerintah dan pengelola lokasi wisata alam gunung. Diharapkan kegiatan semacam ini ke depannya dapat melibatkan pihak-pihak tersebut untuk meraih hasil yang lebih optimal bagi mengatasi persoalan sampah di lokasi wisata alam khususnya di Jawa Barat.

\section{DAFTAR PUSTAKA}

Broder, S. P. (2019). Plastic and Microplastic Litter: A Serious Problem in the Arctic Ocean. EastWest Center.

Darmawan, I. (2020). Peningkatan Kesadaran Akan Pengelolaan Sampah di Desa Cinta Mulya Melalui Workshop Integratif Dan Kreatif. Dharmakarya, 9(4).

Fordian, D., Lavinia, H. A., Rianto, R., \& Azis, E. A. (2017). Penyuluhan Metode Pembuangan Sampah Organik dan Sampah Non Organik Bagi Rumah Tangga di Lingkungan Rw 03 Desa Cisempur, Kec. Jatinangor. Dharmakarya, 6(3), 129-135.

Hamid, I. A., Yahaya, W., \& Asrina, W. (2020). ZeroWaste campaign: Assessment on university student's behaviour, awareness, and impact on plastic products. Malaysian Journal of Social Sciences and Humanities, 5(3), 24-29. 
Hu, P., \& Hu, Y. (2014). The Institute of Mountain Hazards and Environment: Caring for Mountains and Supporting Their Development. Mountain Research and Development, 34(2), 167-169. International Mountain Society.

Indriawati, P., \& Retnowaty, R. (2018). Pemberdayaan Masyarakat Dalam Upaya Pelestarian Ekosistem Pesisir Dan Hutan Mangrove Manggar. Bagimu Negeri: Jurnal Pengabdian Kepada Masyarakat, 2(1), 29-38.

Irawatie, A., Iswahyuni, I., Setiyawati, M. E., \& Afriani, H. F. (2021). Pengelolaan Bank Sampah Berwawasan Lingkungan Sehat di Masa Pandemic Convid 19. Martabe: Jurnal Pengabdian Kepada Masyarakat, 4(3), 970983.
Mubarak, A., Marasabessy, F., \& Aryuni, V. T. (2019). Pendampingan Bank Sampah Online di Kelurahan Makassar Timur, Kota Ternate Menuju Smart Environment. Jurnal Pengamas, 2(1).

Nurfadhilah, Komalasari, I., \& Prabawa, A. (2020). Operasi apik untuk Gunung Cikuray bersih, sehat, dan lestari. As-Syifa: Jurnal Pengabdian dan Pemberdayaan Kesehatan Masyarakat, 1(2), 89-94.

Taufiqurrahman, F. (2021). 1 Ton Sampah Pendaki Ditemukan di Gunung Gede Pangrango. Kompas.com.

Wirawan, J. (2015). Masalah sampah di gunung dan taman nasional Indonesia mengkhawatirkan. $B B C$ Indonesia. 